\title{
STRATEGIJE PODSTICANJA STVARALAŠTVA U NIŽIM RAZREDIMA OSNOVNE ŠKOLE
}

\begin{abstract}
Sažetak: Kreativnost je veoma složen fenomen, koji je od ključne važnosti za ljudsku populaciju. Shodno tome, tema je istraživanja mnogih pedagoga i psihologa. Suština rada svedena je na značaj stvaralaštva, strategije njegovog podsticanja i ulogu nastavnika u tom procesu. Kroz istraživanje koje je realizovano, može se shvatiti značaj podsticanja stvaralačkih sposobnosti. Bez obzira na činjenicu što nauka daje odgovore na brojna pitanja $i$ što znamo osnovne karakteristike i manifestacije pomenutog fenomena, mnoge stvari još uvijek nijesu jasne. $S$ obzirom na takva dešavanja, od ključne važnosti su istraživanja koja bi doprinijela razvijanju svijesti o podsticanju kreativnosti koja treba da postane osnovni zadatak obrazovanja. Predmet ovog rada je ispitivanje $\mathrm{i}$ istraživanje strategija podsticanja stvaralaštva u nižim razredima osnovne škole. Problem datog istraživanja može se izraziti u vidu sledećeg pitanja: Kakve su mogućnosti i efekti strategija podsticanja stvaralaštva u nižim razredima osnovne škole? Cilj rada je da se čitaoci, posebno učitelji, zainteresuju za izabranu temu i prošire svoja znanja o njoj. Analogno tome, cilj je da obrate pažnju na brojne mogućnosti podsticanja stvaralaštva i iskoriste ta znanja kako bi na što bolji način uticali na razvoj kreativnosti svojih učenika. $U$ odnosu na definisan predmet, problem i ciljeve istraživanja proizilazi hipoteza: pretpostavlja se da primjena strategija podsticanja stvaralaštva u velikoj mjeri može podstaći kreativnost i kreativno mišljenje kod učenika drugog razreda. Metode korišćene u radu su metoda teorijske analize, kao i deskriptivna naučno-istraživačka metoda. Metoda eksperimenta s paralelnim grupama koristi se u dijelu rada koji se odnosi na upoređivanje efekata primjene strategija podsticanja stvaralaštva. Istraživanje je sprovođeno tehnikom testiranja i posmatranja. Uzorak čine učenici drugog razreda Osnovne škole „21. maj” iz Podgorice. Nakon sprovedenog istraživanja, zaključuje se da strategije podsticanja stvaralaštva mogu doprinijeti razvoju kreativnosti kod učenika i da su učenici eksperimentalne grupe ostvarili bolje rezultate od učenika kontrolne grupe, u kojoj se nastava izvodila tradicionalno. Kroz ovaj rad, može se shvatiti koliki značaj ima ova tema, posebno za učitelje i sve one koji su dio vaspitno-obrazovnog procesa.
\end{abstract}

Ključne riječi: kreativna nastava; kreativni nastavnik; kreativnost; strategije podsticanja stvaralaštva.

\section{Uvod}

Od nastanka svijeta pa do danas, kreativni umovi pokreću društvo. Na samom početku trebalo je osmisliti oruđe kojim će se ukrotiti razne zvijeri, zatim kako stvoriti sebi skrovište, patentirati točak, struju i tehniku i tehnologiju koju danas poznajemo. Sve što vidimo oko sebe, a rezultat je čovjekovog djelovanja, predstavlja svojevrsno umjetničko djelo i produkt stvaralačkog 
procesa. Navedeni razlozi su više nego dovoljni da bismo razumjeli potrebu za vaspitanjem i obrazovanjem stvaraoca.

Kroz istoriju prate nas različite definicije stvaralaštva. Poistovjećivano je s darom od Boga, $s$ nagradama za dobro djelo koje ljudi dobijaju tokom sna i raznim drugim mitološkim vjerovanjima. Razvojem čovjekove svijesti razvila se i misao o kreativnosti koja se danas povezuje s umijećem stvaranja nečeg novog, neobičnog, promišljenog i iznenađujućeg. Postoje razne definicije stvaralaštva. Poistovjećuju je s talentom, jednim vidom inteligencije, originalnošću, ali bez obzira na raznolikost pri definisanju - svi teoretičari su saglasni da predstavlja skup raznih osobina i vještina (Marinković, 2003).

Kreativnost je složen fenomen koji zaslužuje posebnu pažnju. Izuzetno je važna u vrijeme formiranja ličnosti učenika. Jedna je od najistaknutijih ljudskih sposobnosti i iz tog razloga, predmet je brojih pedagoških istraživanja. Pedagozi, psiholozi, i sociolozi koji su istraživali kreativnost kao fenomen, saglasni su da je kreativno mišljenje najviša mentalna funkcija, a kreativna produkcija vrh ljudskog postignuća (Prtljaga, 2017).

Postavlja se pitanje da li se rađamo kreativni ili se navedena sposobnost vježba i uči raznim tehnikama. Mišljenja stručnjaka su podijeljena, ali je mnogo veći broj onih koji svojim istraživanjima potvrđuju da je kreativnost moguće podsticati (Kvaščev, 1974).

Kreativnost je proces kojim osoba postaje svjesna nekog problema, teškoće ili nedostatka u znanju, za koje ne može da nađe naučeno ili poznato rješenje; ona traži rješenja postavljajući hipoteze; procjenjuje, provjerava i preinačava svoje hipoteze i saopštava rezultate (Kvaščev, 1974:3).

Stvaralaštvo je neizostavan segment napredovanja. Stvaraoca možemo poistovjetiti s genijem koji sopstvenim naporima i aktivnošću dolazi do novih, do sada nepoznatih rješenja. Kreativnošću čovjek ne samo da stvara nove vrijednosti, već olakšava sopstveno funkcionisanje u svakodnevnom životu. Misli i donosi konstruktivna rješenja kojim pobjeđuje brojne izazove.

Smatra se da u stvaranju resursa osnovu čini kreativno društvo, koje se stvara razvojem transferzalnih kompetencija mladih, koje se u Evropskoj uniji smatraju ključnim kompetencijama 21. veka (Gojkov, Stojanović, 2017). Smatra se da su logično razmišljanje, kreativno razmišljanje i kritičko razmišljanje temelj održivog razvoja, pa je potrebno da države u svoje mehanizme društvenog, kulturnog i političkog razvoja uključe kreativno obrazovanje kao jedan od fundamentalnih načina kojim države i njeni građani mogu ići prema dugoročnim razvojnim ciljevima, kao i da uključe sredstva i alate koji omogućuju ostvarenje istih (Gojkov, Stojanović, 2017: 7).

Pregršt osobina koje su međusobno povezane oblikuju stvaraoca. Potrebna je: originalnost, fleksibilnost, stvaralačka fantazija, fluentnost ideja, motivacija, tolerancija prema neodređenosti i još brojne druge osobine (Kvaščev, 1974). Posmatrajući ovaj niz osobina jasno se zaključuje da postati kreativna ličnost nije lak put. Potreban je niz usmjeravanja, rada i potpuna podređenost društva i školstva kako bi se prepoznao, podržao i podstakao kreativni pojedinac. 
Visoka inteligencija je samo jedan od preduslova, a da bi se neko svrstao u grupu darovitih, potrebno je da ima i nekoliko drugih značajnih karakteristika: rano korišćenje širokog rečnika; spretnost u jeziku, korišćenje fraza i celih rečenica u vrlo ranim godinama; opšta zapažanja; interes prema knjigama, kasnije atlasima, enciklopedijama; rani interes za datume i časovnik; sposobnost koncentracije; rano otkrivanje uzroka i posledica (što ih čini emotivno osetljivijima) - Rajović (2018: 16).

Dijete koje pokazuje neke od navedenih karakteristika možemo smatrati mogućim stvaraocem. Važno je prepoznati učenika i zadavati mu zadatke i usmjeravati ga tako da razvija stvaralački duh shodno svojim individulanim sposobnostima. Posmatrajući dječiji crtež, posebno u uzrastu od 6 do 12 godina, možemo saznati mnogo. Ne samo o psihološkim osobenostima djeteta, njegovim relacijama sa okolinom, već i o nivou njegove mašte i stvaralačke prirode (Koks, 2000). Najvažnija stvar je prepoznavanje i adekvatan usmjeren rad sa djecom.

Svjesni uloge kreativnosti u razvoju učenika, pedagozi i u 20. vijeku provlače ideju o kreativnoj nastavi. Posebno se ističu svojim teorijama kreativne nastave Lav Vigotski i Žan Pijaže. Na našim prostorima značajni su: Radivoj Kvaščev, Milan Bakovljev, Mehmed Duraković (Kvaščev, 1974). Bez obzira na prepoznatu ulogu kreativnosti i neophodnost njenog uvođenja u škole, tradicionalna škola još uvijek nije dorasla ovom zahtjevu. Kreativnost je imperativ savremene škole i temelj na kom ona treba da počiva.

Brojni pedagozi su svoj naučno-istraživački rad podredili izučavanju stvaralaštva. Imajući u vidu značaj podsticanja stvaralaštva, razvili su značajne teorije i strategije. Od velikog niza pristupa koji se bave procesom stvaranja i kreativnim učenikom izdvajaju se: Oluja ideja, Kračfildov sistem, Sinektika, Torsanova strategija, Hefelova strategija, Tejlorova strategija razvijanja stvaralaštva i NTC sistem. Sve navedene strategije oslanjaju se na sopstveno viđenje stvaralaštva i sebi osoben način podsticanja pomenutog. Naravno, postoje i brojne sličnosti među različitim strategijama (Gojkov, Stojanović, 2017).

Rješavanje problema Ozbornovom strategijom razvija se kroz dvije etape. U prvoj etapi ideacije, nakon definisanja problema, daju se ideje koje bi mogle predstavljati ili ukazivati na rješenje problema. Dozvoljena je potpuna sloboda u izražavanju ideja i mišljenja. Druga faza je faza kritičnosti. Ideje se analiziraju, o njima se diskutuje, vrednuje se njihov značaj za postavljeni problem. Biraju se najbolje ideje, a zatim se i one rangiraju po određenim pravilima (Kvaščev, 1974).

Sinektika znači povezivanje različitih i na oko nespojivih elemenata. Ova strategija zasniva se na kreativnom povezivanju suprotnih stvari i pojmova, koje na prvi pogled nemaju nikakvih sličnosti. Osnovna metoda rada je analogija. Povezivanje sa pojavama, bićima iz prirode navodi na krajnje rješenje problema. Analogija može biti i poistovjećivanje sopstvene ličnosti sa nekim predmetom, pojavom ili živim bićem (Gojkov, Stojanović, 2017).

Kračfild, Olton i saradnici su razvili strategiju podsticanja stvaralaštva koja se zasniva na teoriji asocijacija, teoriji crta i geštalt teoriji. Autori date strategije podsticanja stvaralaštva su programirali trideset dvije sveske pomoću kojih su razvijali stvaralaštvo. Svaka programirana sveska sadržala se od detektivskih i misterioznih priča; trebalo je da ispitanici riješe te priče (Kvaščev, 1974). 
Torans je zajedno sa svojim saradnicima kroz dvadeset dva eksperimenta istraživao kompetencije nastavnika i njihovu ulogu u podsticanju kreativnosti. Tačnije, ispitivali su kako nastavnik može stvoriti atmosferu pogodnu za podsticanje kreativnosti, na koji način može pomoći djeci da razviju kreativnost, kakvo ponašanje nastavnika je najpogodnije za razvoj kreativnosti. Kroz svoja istraživanja zaključio je da snažan efekat ima ako djeca bivaju nagrađena za kreativno mišljenje (Kvaščev, 1974).

Stvaralaštvo i njegovo podsticanje bilo je predmet rada i psihologa Hefela. On je razvio strategiju baziranu na grupnom, kreativnom rješavanju problema Grupni, kreativan rad je izuzetno podsticajan. Svi članovi grupe su ravnopravni i ravnomjerno doprinose rješenju problema, udruženim snagama. Sumiranjem više ideja članova grupe i stapanjem raznolikih rješenja u jedan dobija se na kvalitetu i originalnosti ideje (Kvaščev, 1981).

Mišljenja da se kreativnost može podsticati bio je i Tejlor. Na osnovu svojih gledišta i istraživanja razvio je strategiju razvijanja stvaralaštva koja se temelji na razvijanju individualnog stila učenja i razvoja kreativnosti i svih njenih aspekata i principa. Podsticanje kreativnih procesa učenika je na maksimalnom stupnju (Kvaščev, 1974).

NTC program stvaralaštva se zasniva na vezama između neurobiologije i kognicije. Utemeljivači ove teorije svoj pristup zasnivaju na što većoj fizičkoj aktivnosti, čulnim doživljajima, logičkim zadacima i na tim osnovama podstiču razvoj mozga i kreativnost. Akcenat se stavlja na veliku važnost ranog stimulisanja djece, jer se proces mijelizacije velikog broja ćelija završava oko sedme godine života (Rajović, 2012).

Stvaralaštvo se može podsticati u školi kroz sve predmete, što je posebno lako sprovodljivo kroz program likovne kulture, muzičke kulture i fizičkog vaspitanja. Svjesni smo činjenice koliko muzika i pokret utiču na razvoj kognitivnih funkcija. Uticaj je posebno značajan kod učenika u nižem uzrasnom periodu osnovne škole. Opšte je poznata činjenica da fizička aktivnost podražava razvoj sinapsi u mozgu, kao i jačanje veza među njima. Dijete treba što više da se slobodno kreće, trči, skače, puzi, penje, okreće se oko svoje ose i da na taj način istražuje svoju okolinu (Rajović, 2018). Boravkom u prirodi djeca će biti u prilici da razvijaju maštu i istraživački duh. Program prirode i društva bi primjenjivanjem raznih eksperimenata, logorovanjem, planinarenjem i zanimljivim radionicama mogao pružiti učenicima krila za kreativan let. Vrijednost književnosti je neosporna za razvoj mašte i stvaralaštva. Adekvatno organizovanom nastavom put stvaraoca bio bi vješto utaban. Časovi matematike u školama se najčešće svode na utvrđenim šablonima, unaprijed pripremljenim formulama i uvježbavanju istih tipova zadataka. Razvojem logike raznovrsnim kreativnim zadacima, rješavanjem zadataka na nekoliko načina, djeca bi se učila divergentnom mišljenju.

Za podsticanje kreativnosti u školi neophodna je i značajna uloga učitelja. Utvrđeno je da se kreativnost razvija do polaska u školu, a da početkom školskog perioda taj razvoj značajno opada ili prestaje. Prethodna rečenica bi svakog savjesnog učitelja trebalo da zabrine. Oštre školske norme i nametnuti sadržaji koji ničim ne pobuđuju kreativnost učenika dovode do pomenutih rezultata (Marinković, 2003). U vrtiću djeca otkrivaju putem slobodne igre, spontano, nenametnuto. U školi, u nižem školskom uzrastu, dječija kreativnost počinje da se sputava. Učitelji plasiraju gradivo, a ono što se od učenika očekuje je da reprodukuju. Na taj način nema razvoja kreativnosti niti pravog stvaralaštva. Vannastavne aktivnosti se ne sprovode na odgovarajući način. Da bi kreativnost učenika nastavila da se razvija istom dinamikom kao u vrtićkom periodu potrebno je obratiti više pažnje na slobodne aktivnosti. 
Niži razredi osnovne škole su hronološki bliski predškolskom periodu i stepen razvoja kreativnosti trebao bi da bude sličan (Janković, 2001).

Učitelj svojim kompetencijama može podstaći i navesti učenike na kreativan proces. Nema stvaralačkog procesa bez motivisanog učitelja. Učitelj treba da bude kompletna ličnost, koja daje primjer učenicima na koji bi trebalo da se ugledaju. Potrebno je da konstantno radi na sebi i na svom stručnom usavršavanju. Važno je da pravilno usmjerava učenike, daje im zadatke koji će podsticati divergentno mišljenje.

Kreativan nastavnik je pre svega u poziciji organizatora, čoveka koji motiviše, modelira, pomaže, istražuje, inicira, podstiče, prati, usmerava i stalno traga za novim vidovima organizacije, nalazeći i sam zadovoljstvo u svojoj kreativnosti i kreativnosti svojih učenika (Marinković, 32003). Bitna osobina kreativnog nastavnika je vedrina, dobro raspoloženje, humor, entuzijazam i kreativan stav prema životu, tj. odstupanje od stereotipa i šablona $\mathrm{i}$ težnja ka novom, originalnom, duhovitom, progresivnom. To znači da kreativan nastavnik treba da je lično opredeljen za kreativnu nastavu, da dobro poznaje prirodu kreativnog procesa i strategiju kreativne nastave (Marinković, ${ }^{3}$ 2003: 19).

\section{Problem i predmet istraživanja}

Školski sistem počiva na paradigmi Jana Amosa Komenskog (lat. Comenius, češ. Jan Amos Komenský), nastaloj prije više od trista godina. Promjene u društvu zahvatile su sve sfere ljudske djelatnosti, osim školstva. Sistem obrazovanja je ključni temelj na kom se može graditi budućnost i koji može obezbijediti kvalitetno usmjeren razvoj društva. Shodno potrebama koje se nameću i koje razvoj tehnike i tehnologije sobom nosi, važno je kod djece stimulisati sticanje funkcionalnih znanja, podsticati kritičko mišljenje i buditi stvaralački duh (Vilotijević, Mandić, 2015). Stvaralaštvo je osnova svih produkata, jer za sve velike i male projekte potrebna je ideja. Kreativan um je um kom se teži i koji bi trebalo da bude glavni ishod obrazovanja. Stvaralaštvo predstavlja sposobnost stvaranja nečeg novog, neobičnog, do sada neviđenog. Da bi djeca postala stvaraoci i razvijala vještinu maštanja, treba ih podsticati. Pedagozi su se bavili stvaralaštvom i njegovim podsticanjem, tako da danas imamo brojne strategije i principe razvijanja stvaralaštva (Gojkov, Stojanović, 2017). Bez obzira na teorijske rasprave o ovom problemu, u praksi skoro da se ne poklanja pažnja kreativnosti i načinima njenog podsticanja.

Predmet istraživanja: Strategije podsticanja stvaralaštva podstiču kreativnost i elemente kreativnosti (originalnost, fleksibilnost, fluentnost, osjetljivost na probleme) u nastavi nižih razreda osnovne škole.

Problem istraživanja: Kakve su mogućnosti i efekti primjene strategija podsticanja stvaralaštva na razvoj originalnosti, fleksibilnosti, fluentnosti, osjetljivosti na probleme u nižim razredima osnovne škole?

\section{Cilj i zadaci istraživanja}

Iz teorijske elaboracije i postavljenog predmeta i problema istraživanja postavlja se cilj istraživanja:

Utvrditi u kojoj mjeri se može podstaknuti kreativnost učenika drugog razreda primjenom strategija podsticanja stvaralaštva i koja je statistička značajnost razlika između eksperimentalne i kontrolne grupe. 
Iz postavljenog cilja proizilaze sljedeći istraživački zadaci:

- Utvrditi odnos odgovora koji pripadaju konvergentnoj i divergentnoj produkciji u kontrolnoj grupi putem inicijalnog testa;

- Utvrditi odnos odgovora divergentne i konvergentne produkcije u eksperimentalnoj grupi putem inicijalnog testa;

- Utvrdivanje odnosa odgovora divergentne i konvergentne produkcije u kontrolnoj i eksperimentalnoj grupi poslije uvođenja eksperimentalnog faktora.

\section{Istraživačke hipoteze}

Osnovna hipoteza: Imajući u vidu prethodno definisan predmet, problem, cilj, istraživačke zadatke i rezultate do kojih su došli prethodni istraživači, pretpostavlja se da se primjenom strategija podsticanja stvaralaštva u velikoj mjeri može podstaći kreativnost i kreativno mišljenje kod učenika drugog razreda.

\section{Pomoćne hipoteze:}

- Pretpostavlja se da će biti veći procenat odgovora koji pripadaju konvergentoj produkciji na inicijalnom testu u kontrolnoj grupi;

- Pretpostavlja se da će biti veći procenat odgovora koji pripadaju konvergentoj produkciji na inicijalnom testu u eksperimentalnoj grupi;

- Pretpostavlja se da će se povećati broj odgovora divergentne produkcije na završnom testiranju i da će ispitanici ekperimentalne grupe ostvariti bolje rezultate od ispitanika kontrolne grupe na završnom testiranju.

\section{Tok istraživanja}

Istraživanjem su obuhvaćena dva odjeljenja drugog razreda Osnovne škole „21. maj” iz Podgorice. Jedno odjeljenje predstavljalo je kontrolnu, a drugo eksperimentalnu grupu. Grupe su izjednačene na osnovu sposobnosti i postignuća u učenju.

Na samom početku, učenicima je dat inicijalni test na osnovu koga je okvirno utvrđen stepen stvaralačkih sposobnosti učenika u obje grupe. Odgovori su prema mišljenju stručnjaka (pedagog, psiholog, profesor razredne nastave) razvrstavani u grupu onih koji pripadaju divergentoj produkciji, konvergentoj produkciji, a u posebnu grupu su svrstani besmisleni odgovori. S učenicima eksperimentalne grupe, tokom perioda od četiri mjeseca, jednom sedmično rađene su razne edukativne, kreativne i istraživačke radionice. Cilj radionica je podsticanje stvaralačkih sposobnosti: fleksibilnosti, fluentnosti, originalnosti i elaborativnosti.

Sadržaj radionica bio je raznolik, oslanjao se na program pojedinačnih školskih predmeta, ali i integraciju između dva ili više predmeta. S učencima eksperimentalne grupe su rađene:

- muzičke radionice;

- likovne radionice;

- čitalačke radionice;

- na osnovu pročitane lektire „Pinokio” pravili su likove, scenario i realizovali lutkarsku predstavu;

- igra je bila u središtu vaspitno-obrazovnog procesa, obilježili su Dan igre;

- motivisani su kroz detektivske priče;

- razvijali su kreativno mišljenje kroz preporučene NTC zagonetke i priče;

- učestovali su na javnim nastupima; 
- podsticani su kroz saradnju s lokalnom zajednicom, posjete - imali su priliku da se upoznaju s ljudima iz različitih profesija, znamenitostima, ustanovama i saznaju više o tome;

- kroz radionicu ogranizovanu uz predavača mentalne aritmetike Suan Pan;

- izvodili su eksperimente;

- pet dana su pohađali „Školu u prirodi”, poseban oblik nastave tokom kog su imali razne radionice, organizovane fizičke aktivnosti, maskenbale, plivanje i slično;

- tokom trajanja istraživanja tri puta sedmično su prolazili razne poligone, igrali timske, štafetne igre;

- tokom trajanja istraživanja na časovima redovne nastave podsticani su kroz razne problemske zadatke, prilagođene nastavne listiće i rad;

- učestovali su na vannastavnim aktivnostima: ritmička sekcija, ekološka sekcija, šahovska sekcija, recitatorsko-dramska sekcija i sekcija mali matematičari.

Učenici kontrolne grupe nastavu su pohađali redovno, na osnovu utvrđenog plana i programa, bez dodatnih motivacija i stimulacija.

Nakon perioda od četiri mjeseca, objema grupama dat je isti finalni test, putem koga je na osnovu odgovora utvrđen stepen divergene produkcije, konvergentne produkcije u eksperimentalnoj i kontrolnoj grupi nakon podsticanja stvaralaštva u eksperimentalnoj grupi; odnos između kontrolne i eksperimentalne grupe; razlike između početnog i finalnog stanja.

\section{Definisanje varijabli}

Nezavisna varijabla: Organizacija nastave primjenom strategija podsticanja stvaralaštva (Kračfildove, Tejlorove, Toransove, Sinektika, Gardnerove, Hefelove, NTC) kod učenika drugog razreda. Riječ je o nezavisnoj varijabli koja u ovom istraživanju ima ulogu eksperimentalnog faktora.

Zavisne varijable: u ovom istraživanju predstavljaju očekivani efekti nastali pod uticajem eksperimentalnog faktora - strategija podsticanja stvaralaštva, a to su kreativne sposobnosti učenika (originalnost, fleksibilnost, fluentnost, osjetljivost na probleme).

\section{Metode, tehnike i instrumenti istraživanja}

U ovom istraživanju će se koristiti metoda teorijske analize, kao i deskriptivna naučnoistraživačka metoda. Metoda eksperimenta s paralelnim grupama koristila se u dijelu rada koji se odnosi na upoređivanje efekata primjene strategija podsticanja stvaralaštva. Istraživanje se sprovelo tehnikom testiranja i posmatranja. Testiranje se sprovelo upotrebom testova ${ }^{2}$ kojima se utvrdio nivo stvaralačkog mišljenja učenika prije i nakon eksperimenta, kao i međusobni odnos rezultata između eksperimentalne i kontrolne grupe. Istraživanje je praćeno putem tehničkih sredstava (fotografije, video-zapisi) na osnovu čega su psiholozi i pedagozi,

\footnotetext{
2 Pouzdanost ove baterije, procenjivana je,,alfa" koeficijentom. Istim koefijentom ispitivana je i ekvivalentnost učešća djelova baterije u mjerenju kreativnosti. Kronbahov koeficijent korelacije ili tzv. „alfa” koeficijent pouzdanosti iznosi 0,741, što se uzima kao visoka pouzdanost na nivou 0,01. Subtestovi imaju nižu relijabilnost, ali zadovoljavajuću. Diskriminativnost subtestova rađena je preko X2 testa. Validnost ukupne baterije i subtestova kreativnosti rađena je point-biserijskim koeficijentom korelacije i faktorskom analizom. Koeficijent valdnosti je 0,799 , dakle kompozitna validnost baterije je visoka. Visoki komunaliteti u faktorskoj analizi, kao i djelovi varijanse i kovarijanse djelova baterije su indikatori dobre interne konzistentnosti baterije, što je indikator validnosti iste.
} 
angažovani za procjenu rezultata i efekata istraživanja, imali uvid u tok istraživanja. $\mathrm{Na}$ inicijalnom testu postavljeno je pitanje kako je moguće upotrijebiti kartonsku kutiju, a na finalnom kako je moguće upotrijebiti šerpu. Zavisno od toga da li odgovor predstavlja realnu upotrebu predmeta ili je predmet upotrijebljen na nov, nesvakidašnji način odgovori su se kategorisali od strane stručnih lica.

\section{Populacija i uzorak}

Populaciju čine svi učenici drugog razreda osnovnih škola na području opštine Podgorica školske 2018/2019. godine. Uzorak čine učenici drugog razreda Osnovne škole „21. maj” u Podgorici. Obuhvaćeni su učenici dva odjeljenja: jedno odjeljenje koje predstavlja eksperimentalnu grupu i jedno odjeljenje kontrolne grupe. Kada je u pitanju škola iz koje je odabran uzorak, riječ je o prigodnom uzorku, koji je odabran po sopstvenom nahođenju, zbog rada u pomenutoj školi. Odjeljenja eksperimentalne i kontrolne grupe izvučena su metodom „lutrijskog ključa”. U grupama je bilo po 22 učenika. Približan broj dječaka i djevojčica. U eksperimentalnoj grupi je bilo 11 dječaka i 11 djevojčica, dok je u kontrolnoj bilo 14 djevojčica i 8 dječaka. Istog su uzrasnog perioda i sličnih školskih postignuća. Djeca su prema analizi školskih postignuća imali sličan broj učenika sa odličnim, vrlodobrim, dobrim i dovoljnim uspjehom. Učenici kontrolne grupe imaju neznatno bolje rezultate kada se analiziraju školske ocjene od učenika eksperimentalne grupe.

\section{Organizacioni, kadrovski, vremenski plan istraživanja}

Istraživanje je realizovao autor ovog projekta. U klasifikovanju odgovora učenika i kategorisanju pripadnosti istih divergentoj ili konvergentoj produkciji konusultovani su pedagog i psiholog. Istraživanja je trajalo, imajući u vidu sve etape počev od definisanja problema i prikupljanja i konsultovanja literature, zaključno sa pisanjem izvještaja istraživanja, od 15. januara 2019. do 15. septembra 2019. godine.

\section{Rezultati i diskusija istraživanja}

Na inicijalnom testu od učenika obje grupe traženo je da napišu kako sve mogu upotrijebiti kartonsku kutiju. Rezultati koji su dobijeni nakon inicijalnog testa u kontrolnoj grupi biće prikazani u narednoj tabeli. U Tabeli 1 su jasno prikazani primjeri odgovora koji pripadaju divergentnoj produkciji ukoliko su u njima prepoznati elementi originalnosti, fleksibilnosti, fluentnosti, osjetljivosti na probleme. S druge strane izdvojeni su odgovori koji pripadaju konvergentnoj produkciji, jer predstavljaju realnu upotrebu predmeta i nijesu prepoznate navedene osobine kreativnog mišljenja, a posebnu kategoriju čine i besmisleni odgovori.

Tabela 1. Odgovori na inicijalnom testu (kontrolna grupa)

\begin{tabular}{|c|c|c|}
\hline \multicolumn{3}{|c|}{ Kontrolna grupa - odgovori inicijalnog testa } \\
\hline Divergentna produkcija & Konvergentna produkcija & Besmisleni odgovori \\
\hline da se vozi po parketu & za čuvanje knjiga, albuma, omiljenih stvari; da & makaze; krava; avion; \\
kao auto; za & stavljamo viljuške i kašike; napravila bih kuću; & parket; pauk; lenjir; lopta; \\
dobacivanje, umjesto & kutija za igračke; kućica za ljubimce; za crtanje; & sveska; da se pliva; \\
lopte; & može da se od nje nešto napravi; da napravim & \\
& kantu za smeće; za televizore, razne uređaje; & \\
& možemo da je režemo i pravimo oblike; za garažu & \\
& za automobile; da čuvamo sličice; & \\
\hline
\end{tabular}


U dijagramu koji slijedi (v. Prikaz 1) lako je uočljiva prava slika stanja i odnos između odgovora konvergentne i divergentne produkcije. Primjećuje se razlika u procentima između odgovora koji pripadaju divergentoj i odgovora koji pripadaju konvergentoj produkciji. Veći broj odgovora pripada konvergentoj produkciji.

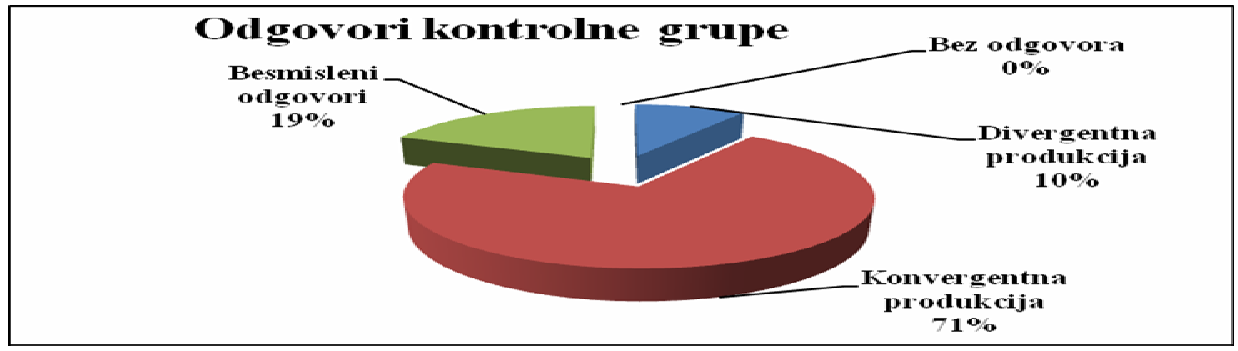

Prikaz 1. Rezultati inicijalnog testa (kontrolna grupa)

Od ukupno dvadeset i jednog učenika, 10\% učenika je dalo odgovor koji pripada divergentoj produkciji, 71\% odgovora pripadao je konvergentoj produkciji. Ukupno 19\% učenika dalo je besmislene odgovore, niko nije bio bez odgovora. (Neki odgovori su se ponavljali, ali su u tabeli navođeni jedan put.)

Odgovori inicijalnog testiranja, učenika koji su pripadali eksperimentalnoj grupi prikazani su u narednoj tabeli (Tabela 2). Od učenika eksperimentalne grupe traženo je da odgovore na isto pitanje kao učenici kontrolne grupe.

Tabela 2. Odgovori na inicijalnom testu (eksperimentalna grupa)

\begin{tabular}{|c|c|c|}
\hline \multicolumn{3}{|c|}{ Eksperimentalna grupa - odgovori inicijalnog testa } \\
\hline Divergentna produkcija & Konvergentna produkcija & Besmisleni odgovori \\
\hline bazen za barbike; može da & za krevet za lutke; za igračke; za sto; za kutiju & karte; za nagradu; može \\
se oboji i napravi kao & za knjige; kao kanta za smeće; za uspomene; da & ruža; olovka; kartonska \\
planina; može da se napravi & čuvamo staru odjeću; možemo napraviti & kutija; odijelo; smajlija; \\
scena za lutke/ pozornica; & saksiju; da se stave školjke; da čuvamo staklene & medvjeda; slovo; žabu; \\
dvorac od kutija; da nam u & stvari i lijekove; kućica za ptice; za reciklažu & \\
igri bude staklenik za & smeća; za pisma, da čuvamo kornjače; možemo & \\
povrće; & staviti šampone i sapune; kutija za nakit; za & \\
& bombice za jelku; kao kavez; bubanj; & \\
\hline
\end{tabular}

Sljedeći dijagram (v. Prikaz 2) jasno prikazuje dobijene podatke i odnose među njima. Razlika između odgovora divergentne i konvergentne produkcije je u datom dijagramu više nego očigledna.

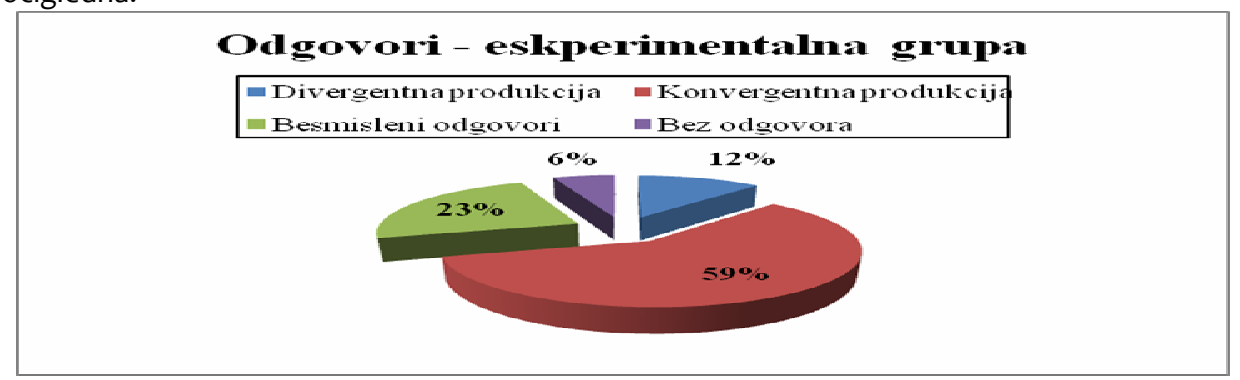

Prikaz 2. Rezultati na inicijalnom testu (eksperimentalna grupa) 
Analizirajući prethodni dijagram dolazi se do sljedećih podataka. Najveći broj odgovora pripadao je konvergentnoj produkciji i to $59 \%$, besmislenih odgovora je bilo $23 \%$, odgovora kojih pripadaju divergentnoj produkciji je bilo $12 \%$, a bez odgovora je $6 \%$.

Uporednom analizom inicijalnog stanja u eksperimentalnoj i kontrolnoj grupi donosi se zaključak da je u obje grupe veći procenat odgovora koji pripadaju konvergentnoj produkciji. Besmislenih odgovora je bilo više u eksperimentalnoj grupi, ali je i bilo više odgovora koji pripadaju divergentnoj produkciji. U kontrolnoj grupi nije bilo učenika koji su bili bez odgovora, dok u eksperimentalnoj grupi jeste. Eksperimentalna i kontrolna grupa imaju približno iste rezultate na inicijalnom testu.

Nakon eksperimentalnog faktora koji je uveden u eksperimentalnu grupu učenicima kontrolne i eksperimentalne grupe, dat je finalni test. Od učenika se tražilo da odgovore na pitanje kako sve mogu upotrijebiti šerpu. U sljedećoj tabeli (Tabela 3) navedeni su odgovori kontrolne grupe na finalnom testu.

Tabela 3. Odgovori finalnog testa (kontrolna grupa)

\begin{tabular}{|c|c|c|}
\hline \multicolumn{3}{|c|}{ Kontrolna grupa - rezultati finalnog testa } \\
\hline Divergentna produkcija & Konvergentna produkcija & Besmisleni odgovori \\
\hline $\begin{array}{l}\text { ako se stidiš jer si ćelav } \\
\text { da se sakriješ; kao šlem } \\
\text { i štit; }\end{array}$ & $\begin{array}{l}\text { da u njoj držim lutke; da se igram kuhinje; da } \\
\text { kuvam jaje; da sjednemo na šerpu; da kuvamo } \\
\text { doručak, ručak, večeru; da se igram kuvara, da } \\
\text { kupam lutke; kao kapa za Snješka Bjelića; možeš } \\
\text { nešto sipati; da udaram i proizvodim neke } \\
\text { zvukove; da se peru krpe i neka roba; }\end{array}$ & $\begin{array}{c}\text { kolekcija lišća; šerpi ima } \\
\text { raznih veličina; }\end{array}$ \\
\hline
\end{tabular}

Veliki broj učenika kontrolne grupe ponavljao je iste odgovore. Nije bilo učenika koji nijesu odgovorili na pitanje. U narednom dijagramu (v. Prikaz 3) jasno je prikazan odnos odgovora divergentne i konvergentne produkcije, kao i onih koji su besmisleni.

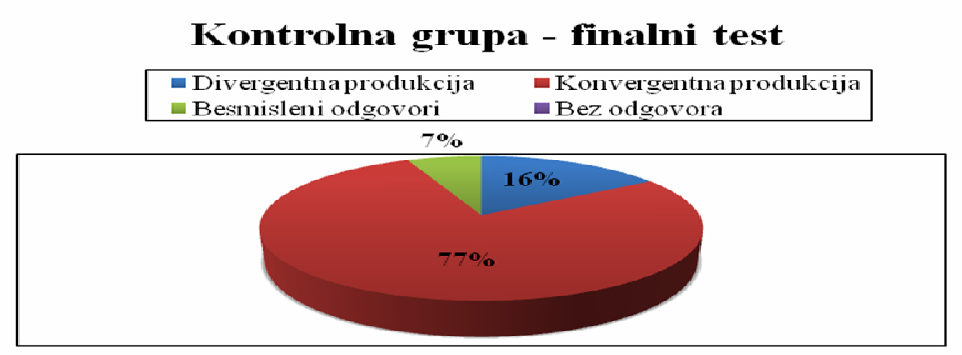

Prikaz 3. Rezultati na finalnom testu (kontrolna grupa)

Najveći broj odgovora pripada konvergentnoj produkciji, čak 86\%. Odgovori koji pripadaju divergentnoj produkciji su 7\% i izjednačeni su s procentom besmislenih odgovora.

Učenici eksperimentalne grupe odgovorili su na isto pitanje nakon četvoromjesečnog podsticanja od strane učiteljice. Njihovi odgovori prikazani su u narednoj tabeli, Tabeli 4. 
Tabela 4. Odgovori na finalnom testu (eksperimentalna grupa)

\begin{tabular}{|c|c|c|}
\hline \multicolumn{3}{|c|}{ Eksperimentalna grupa - završni test } \\
\hline Divergentna produkcija & Konvergentna produkcija & Besmisleni odgovori \\
\hline meta za gađanje; kao raketne & učionica za lutke; za akvarijum; za bubanj; & za jo-jo; kao sijalicu; za \\
čizme; kao ljuljaška - zakačim & kao saksiju; kao sto; kao točak; kapa za & muzičku kutiju; futrola; \\
ručke konopom, pa za drvo; & Snješka Bijelića; da u njoj čuvamo sprejeve; & šuma; za učenje slova; \\
kad zalijepiš trakice oko nje & da čuvamo ribice; kutija za eksere; da u njoj & okrugla šerpa; \\
može da bude Sunce; & stavim miša kao ljubimca; kuvanje & \\
& makarona; kanta za smeće; posuda za & \\
& mačke i pse; da se pravim da sam kuvar; & \\
\hline
\end{tabular}

Procenat odgovora i razmjeru između odgovora kod učenika eksperimentalne grupe jasno se vidi u narednom dijagramu (v. Prikaz 4).

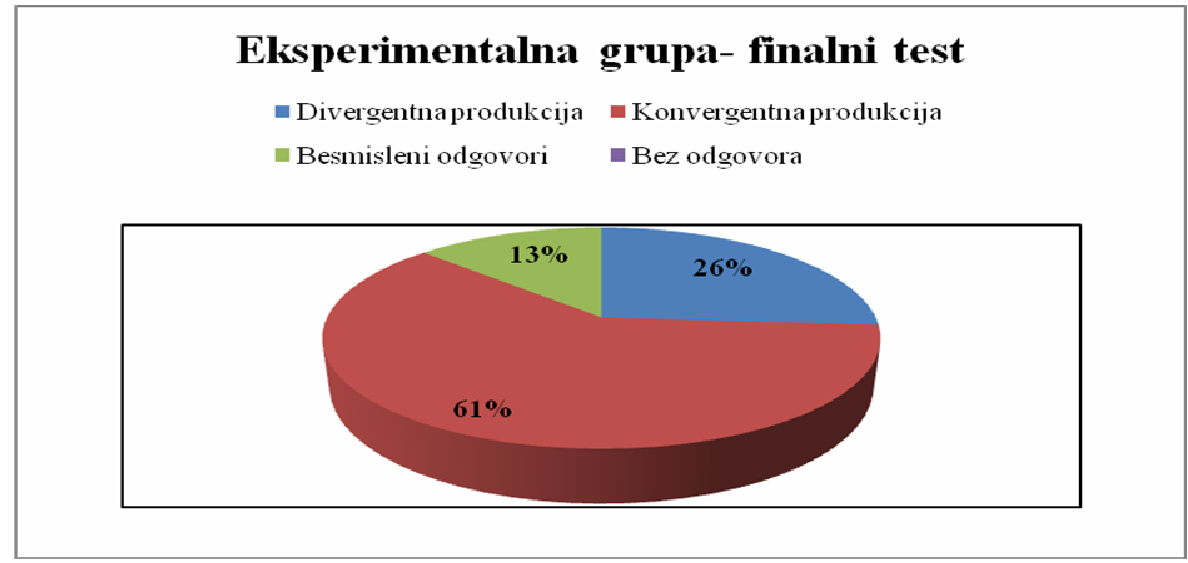

Prikaz 4. Odgovori eksperimentalne grupe - finalni test

Uvidom u prethodni dijagram dobijamo sljedeće podatke. $63 \%$ odgovora pripada konvergentnoj produkciji, 23\% pripada divergentnoj produkciji, dok je besmislenih odgovora $14 \%$. Nije bilo učenika koji nijesu odgovorili na pitanje. Jasno se uočava da je najveći broj odgovora koji pripadaju konvergentoj produkciji.

Uporednom analizom rezultata finalnog testa kontrolne i eksperimentalne grupe primjećuje se da je u obje grupe veći procenat odgovora koji pripada konvergentoj produkciji (v. Grafički prikaz 5). Učenici kontrolne grupe davali su šablonske i ustaljene odgovore, dok su učenici eksperimentalne grupe i u davanju odgovora u okviru konvergentne produkcije bili raznolikiji. $\mathrm{Na}$ završnom testiranju i kontrolne i eksperimentalne grupe nije bilo učenika koji nijesu odgovorili na pitanje. U kontrolnoj grupi primjećuje se pad broja odgovora koji pripadaju divergentnoj produkciji u odnosu na inicijalni test, dok se kod eksperimentalne grupe taj procenat povećao. $U$ eksperimentalnoj grupi je veći procenat besmislenih odgovora, što je bio slučaj i sa inicijalnim testiranjem. 


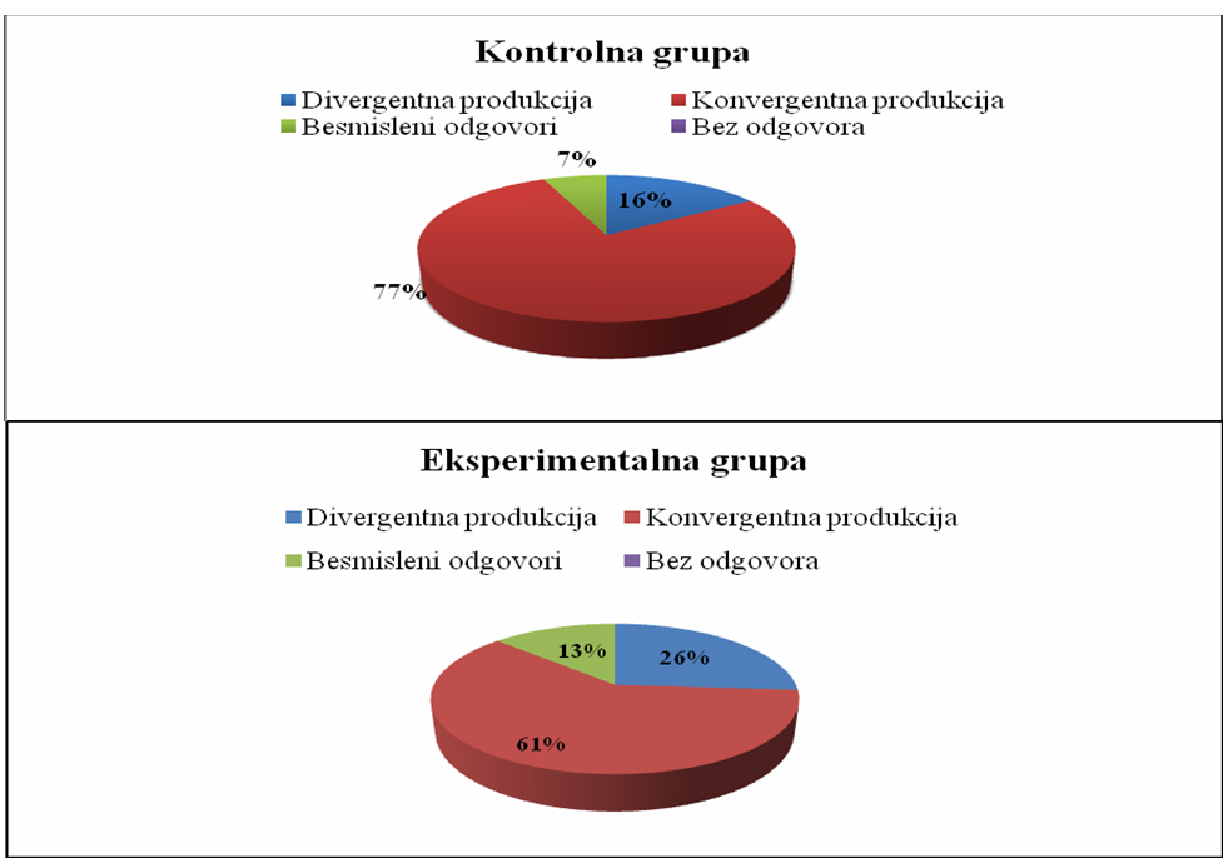

Prikaz 5. Uporedna analiza rezultata finalnog testa

Statistička razlika rezultata eksperimentalne grupe inicijalnog u odnosu na finalni test je 0.187548298 , što predstavlja statistički značajnu razliku jer je $r>0,05$. Razlika rezultata eksperimentalne u odnosu na kontrolnu grupu na finalnom testu je 0.254617389 , što je statistički značajna razlika.

\section{Zaključak}

Prepoznavanje značaja stvaralaštva i njegovo podsticanje važno je za sve učitelje i one koji se bave vaspitno-obrazovnim radom. Pravilnim podsticanjem učenika, putem poznatih strategija, kroz prilagođen program školskih predmeta i vannastavnih aktivnosti može se učiniti mnogo u domenu stvaralačkih sposobnosti učenika.

Dato istraživanje usmjereno je na efekte podsticanja stvaralaštva učenika u drugom razredu osnovne škole. Analizirajući rezultate koji su dobijeni istraživanjem, zaključuje se da je opšta hipoteza: primjenom strategija podsticanja stvaralaštva se u velikoj mjeri može podstaći kreativnost i kreativno mišljenje kod učenika drugog razreda - potvrđena. Pomoćne hipoteze su potvrđene, takođe, s tim da je treća hipoteza djelimično potvrđena, jer je broj odgovora divergentne produkcije na završnom testiranju povećan kod eksperimentalne grupe, ali je kod kontrolne grupe smanjen.

Istraživanje predstavlja skroman doprinos težnji da se shvati značaj stvaralaštva i podsticanja razvoja stvaralačkih sposobnosti učenika. Osim toga, upućuje na odgovornost i veliki uticaj nastavnika i škole na razvoj kreativnosti. Vrijeme je da se probudi svijest o važnosti njegovanja kreativnih umova, jer vaspitanjem i obrazovanjem stvaraoca činimo siguran korak u kvalitetnu budućnost. 


\section{Literatura}

Gojkov, G., Stojanović, A. (2017). Didaktičke strategije i divergentna produkcija. Beograd: Srpska akademija obrazovanja.

Janković, P. (2001). Vannastavne aktivnosti i učeničko stvaralaštvo. Norma, VIII, 59-79.

Koks, M. (2000). Dečiji crteži. Beograd: Zavod za udžbenike i nastavna sredstva.

Kvaščev, R. (1974). Razvijanje stvaralačke sposobnosti kod učenika. Beograd: Zavod za udžbenike i nastavna sredstva.

Kvaščev, R. (1974). Razvoj kreativnog ponašanja ličnosti. Beograd: Zavod za udžbenike i nastavna sredstva.

Kvaščev, R. (1981). Psihologija stvaralaštva. Beograd: Zavod za udžbenike i nastavna sredstva.

Marinković, S. (32003). Metodika kreativne nastave srpskog jezika i književnosti. Beograd: Kreativni centar.

Prtljaga, S. (2017). Projekt metoda kao faktor podsticanja kreativnosti učenika. Beograd: Učiteljski fakultet.

Rajović, R. (2012). Kako uspešno razvijati IQ deteta kroz igru. Novi Sad: Smart production.

Rajović, R. (2018). IQ deteta briga roditelja. Novi Sad: Smart production.

Vilotijević, M., Mandić, D. (2015). Upravljanje razvojnim promenama u vaspitno-obrazovnim ustanovama. Beograd: Učiteljski fakultet.

\section{Biografska nota}

Snežana Leovac je rođena 11. februara 1993. godine u Podgorici. Završila je Filozofski fakultet u Nikšiću i Master studije za obrazovanje učitelja u Beogradu. 